\title{
Viral exposure and abnormal liver function in haemophilia
}

\author{
B. A. MCVERRY ${ }^{1}$, M. G. R. ROSS, WENDY A. KNOWLES, AND \\ JENNIFER VOKE \\ From the Haemophilia Centre, Department of Haematology and Department of Virology, Royal Free \\ Hospital, and Virus Reference Laboratory, Colindale Avenue, London, UK
}

SUMMARY Several studies have recently documented the presence of persistently abnormal liver function tests in asymptomatic haemophiliacs. While the aetiology is unknown it is possible that repeated exposure to agents transmitted in blood products may be important. This study has attempted to determine the prevalence of viral exposure and its relationship to liver function in this multitransfused group of individuals. The prevalence of viral antibodies with the exception of antibody to hepatitis B surface antigen (anti-HBs) and cytomegalovirus (CMV) was normal when compared to that in the general population. Hepatitis B surface antigen (HBsAg) was not detected, but anti-HBs was found in $83 \%$ of patients; $50 \%$ of patients had abnormal liver function. However, liver function tests were normal in all patients with mild haemophilia and were only rarely abnormal in patients who had no detectable antibody to CMV, Epstein-Barr virus (EBV), and HBsAg. This study demonstrates that multiple transfusions of blood products, that is, cryoprecipitate and factor concentrates, do not increase the risk of exposure to the viruses studied with the exception of hepatitis B virus.

Haemophiliacs are a group of multitransfused individuals often requiring weekly infusions of factor VIII, either to treat bleeding episodes or as part of a prophylactic regimen. Cryoprecipitate is still the mainstay of therapy in the United Kingdom, although lyophilised factor VIII concentrates are being used increasingly.

Hepatitis in patients receiving whole blood has been well documented (Wallace, 1976). While clinical hepatitis after transfusion of blood products is uncommon in haemophiliacs (Lewis, 1970; Biggs, 1974), several reports have appeared in the literature documenting the presence of persistent abnormalities of liver function tests in the majority of these patients (Mannucci et al., 1975; Hasiba et al., 1977; Hilgartner and Giardina, 1977; Levine et al., 1977; McVerry et al., 1977; Sultan et al., 1977; Webster et al., 1977; Yannitsiotis et al., 1977). These studies suggest that abnormal liver function tests:

(1) are present in over $50 \%$ of patients;

(2) are not associated with symptomatic evidence of liver disease;

${ }^{1}$ Present address: Department of Haematology, University College Hospital, London

Received for publication 22 August 1978
(3) are not related to the intensity of factor VIII or IX replacement therapy, the age of the patient, or the underlying nature of the haemostatic defect, ie, haemophilia, Christmas disease, or von Willebrand's disease (Hilgartner and Giardina, 1977); and

(4) tend to persist over at least a one-year period.

One study suggested that abnormal liver function was more frequent in patients receiving lyophilised factor concentrates than in those receiving cryoprecipitate (Hasiba et al., 1977), but this has not been found by others (Levine et al., 1977; McVerry et al., 1977).

The aetiology and long-term significance of these findings are unknown. While investigators are obviously reluctant to perform liver biopsies, a recent study gives cause for some concern (Lesesne et al., 1977). Liver biopsies were performed on six haemophiliacs who had abnormal liver function tests persisting for at least six months. Three patients had chronic active hepatitis and three chronic persistent hepatitis. These findings have since been confirmed (Spero et al., 1978). While the numbers of patients in these studies were small, they nevertheless provide definitive evidence for the existence of chronic hepatitis in haemophiliacs. It is possible that the complications of treatment, that is, liver 
disease, may become a significant cause of morbidity and mortality as haemorrhagic complications are reduced with improved replacement therapy. In this regard, it has been noted that cirrhosis has not been a major cause of death in haemophiliacs (Aledort, 1977).

Other related observations include the high incidence of splenomegaly (Levine et al., 1977) and circulating immune complexes (McVerry et al., 1977) in haemophiliacs.

It has been suggested that these findings may be related to an infective agent or agents transmitted by blood or blood products. In support of this, significantly higher titres to cytomegalovirus have been found in haemophiliacs than in controls (Levine et al., 1977). Whether this represented primary infection or viral reactivation is not known.

This study has attempted to answer two questions:

(1) whether the incidence of viral exposure is greater in this multitransfused group of patients than in the general population; and

(2) whether there is any relationship between the viruses studied and the presence of abnormal liver function tests.

\section{Patients and methods}

Forty-two patients attending the Royal Free Hospital Haemophilia Centre were investigated. Thirty-eight were factor VIII deficient and four were factor IX deficient; 30 were severely affected (factor VIII or IX less than $2 \mathrm{IU} / \mathrm{dl}$ ), four moderately severe (2-5 IU/dl), and eight mild (more than $5 \mathrm{IU} / \mathrm{dl}$ ). The age range was 6-55 years with one patient under the age of 10,15 between 10 and 19 years, 14 between 20 and 39 years, and 12 over 40 years old.

Information regarding the type of replacement therapy and amount of treatment given during the six months immediately before this study was available on all patients; 28 had received only cryoprecipitate, seven only factor VIII or IX concentrate, and two both cryoprecipitate and factor concentrate. Five patients had factor VIII antibodies and had received no replacement therapy during this period. In most cases, the quantity of replacement therapy was directly proportional to the severity of the disease. The majority of patients in this study group had received occasional whole blood transfusions in the past.

The following studies were performed at the Virus Reference Laboratory. Hepatitis B surface antigen (HBsAg) was detected by reverse passive haemagglutination (Hepanosticon). Antibody to HBsAg (anti-HBs) was determined by a passive haemagglutination technique, and sera found to be negative were then tested by radioimmunoassay. Sera were screened at a $1 / 2$ dilution for complementfixing antibody to cytomegalovirus (CMV) and the positives were titrated. CMV-specific IgM antibody was detected by an indirect fluorescent antibody test at a serum dilution of $1 / 4$. Isolation of CMV from urine was attempted on cultures of human embryo fibroblasts maintained for four weeks at $37^{\circ} \mathrm{C}$. Indirect immunofluorescence tests for IgG and IgM antibodies to Epstein-Barr virus (EBV) capsid antigen were performed by Dr. J. M. B. Edwards of the Virus Reference Laboratory.

Antibody to influenza virus types $\mathrm{A}$ and $\mathrm{B}$, adenovirus, respiratory syncytial virus, measles, rubella, herpes simplex, varicella-zoster, and mumps viruses and Mycoplasma pneumoniae was measured by a standard complement fixation technique (Bradstreet and Taylor, 1962) in the Department of Virology, Royal Free Hospital. Titres of $1: 8$ or greater were accepted as evidence of previous exposure. Sera were tested for antibody to hepatitis A virus (anti-HAV) using a radioimmunoassay test kit (HAVAB ${ }^{\mathrm{TM}}$; Abbot Diagnostic Laboratories: Thornton et al., 1977). Serum bilirubin, albumin, and aspartate transaminase were measured by standard techniques.

\section{Results}

CMV AND EBV

Twenty-six patients (62\%) had complement fixing antibodies to CMV. All titres were low $(1: 8$ to $1: 64)$ and did not suggest a recent primary infection. The incidence of CMV antibody increased with age (Table 1 ), and 11 patients $(92 \%)$ over the age of 40 years had antibody indicating an unusually high exposure rate in this population. CMV was isolated from the urine of two patients aged 6 and 25 years. Both had complement fixing antibody, but in neither could CMV-specific IgM antibody be detected. Thirty patients $(71 \%)$ had antibody to EBV and the prevalence increased with age (Table 1). In three patients a positive result was obtained in the tests for CMV and EBV IgM, but in each case rheumatoid factor was detected, which in the presence of specific IgG can result in a false-positive reaction in an IgM indirect immunofluorescence test. The monospot test was negative in these patients.

HBSAg AND ANTI-HBS

In no patient was HBsAg detected although $35(83 \%)$ had anti-HBs. The incidence of anti-HBs did not increase with advancing age (Table 1). 
Table 1 Association between age, antibody to CMV, EBV, and HBsAg and liver function in 41 haemophiliacs*

\begin{tabular}{lllllll}
\hline Age (years) & $\begin{array}{l}\text { Number of } \\
\text { patients }\end{array}$ & \multicolumn{2}{l}{ Positive serology } & & \multicolumn{2}{l}{ Liver function tests } \\
\cline { 2 - 5 } \cline { 5 - 7 } & CMV & EBV & HBsAg & Normal & Abnormal \\
\hline $10-19$ & 15 & $7(47)$ & $7(47)$ & $13(87)$ & $9(60)$ & $6(40)$ \\
$20-39$ & 14 & $7(50)$ & $11(78)$ & $13(93)$ & $8(57)$ & $6(43)$ \\
$>40$ & 12 & $11(92)$ & $11(92)$ & $9(75)$ & $4(33)$ & $8(67)$ \\
\hline
\end{tabular}

* One patient aged 6 years is not included.

Percentages are given in parentheses.

OTHER VIRUSES AND MYCOPLASMA

PNEUMONIAE

The incidence of antibodies detected is shown in Table 2. These values are within the normal range for the general population, and titres were generally low $(1: 8$ to $1: 64)$. Anti-HAV was present in $46 \%$ of patients; the prevalence did not increase with advancing age.

Table 2 Prevalence of viral and Mycoplasma pneumoniae antibodies detected in 24 haemophiliacs

\begin{tabular}{lc}
\hline Virus & $\begin{array}{l}\text { No. of patients with } \\
\text { antibody }(\%)\end{array}$ \\
\hline Adenovirus & $13(54)$ \\
Hepatitis A virus & $11(46)$ \\
Herpes simplex & $14(60)$ \\
Influenza A & $19(83)$ \\
Influenza B & $11(46)$ \\
Measles & $17(71)$ \\
Mumps & $11(46)$ \\
Respiratory syncytial virus & $8(33)$ \\
Rubella & $10(40)$ \\
Varicella-Zoster & $6(25)$ \\
Mycoplasma pneumoniae & $15(62)$ \\
\hline
\end{tabular}

LIVER FUNCTION TESTS

Twenty-one patients (50\%) had elevated levels of aspartate transaminase. The range for all patients was 7-194 IU/1 (normal 4-15 IU/1). Serum bilirubin was abnormal in three patients $(7 \%)$. Serum albumin was normal in all patients. Only one patient had symptoms of liver disease and he had well documented primary biliary cirrhosis. The incidence of abnormal liver function tests in different age groups is shown in Table 1. These findings are similar to those previously reported by us (McVerry et al., 1977).

\section{CORRELATION BETWEEN LIVER FUNCTION} TESTS AND VIRAL STUDIES

The relationship between antibodies to CMV, EBV, and HBsAg and liver function tests is shown in Table 3. All but one of the patients with abnormal liver function had anti-HBs; most of them also had antibody to CMV and EBV. There was no correlation between the presence of antibody to Mycoplasma pneumoniae or the other viruses studied, including hepatitis A, and abnormal liver function tests.

CORRELATION BETWEEN INTENSITY OF REPLACEMENT THERAPY, VIRAL EXPOSURE, AND LIVER FUNCTION

The correlation between severity of haemophilia, liver function tests, and antibody to CMV, EBV, and HBsAg is shown in Table 4.

In most patients the quantity of replacement therapy correlated well with the severity of haemophilia. All eight patients with mild haemophilia and a history of infrequent factor VIII infusions had normal liver function tests. These also tended to have a lower prevalence of antibodies to CMV, EBV, and HBsAg.

\section{Discussion}

Viruses can be transmitted by whole blood transfusions and produce hepatitis. HBsAg, CMV, and EBV have been incriminated as aetiological agents in some patients (Wallace, 1976), while others appear to be infected with as yet unidentified organisms, that is, hepatitis non-A, non-B (Alter et al., 1978). Haemophiliacs are an unusual group of patients in that they may be repeatedly exposed to blood-

Table 3 Antibodies to $C M V, E B V$, and $H B s A g$ and their relationship to liver function tests (LFTs) in 42 haemophiliacs

\begin{tabular}{|c|c|c|c|c|c|c|c|}
\hline & \multirow{2}{*}{$\begin{array}{l}\text { Number } \\
\text { of } \\
\text { patients }\end{array}$} & \multicolumn{2}{|c|}{$C M V C F$ antibody } & \multicolumn{2}{|c|}{$E B V \operatorname{Ig} G$ antibody } & \multicolumn{2}{|c|}{ Anti-HBs antibody } \\
\hline & & Positive & Negative & Positive & Negative & Positive & Negative \\
\hline $\begin{array}{l}\text { Patients } \\
\text { Patients with abnormal LFTS } \\
\text { Patients with normal LFTS }\end{array}$ & $\begin{array}{l}42 \\
21 \\
21\end{array}$ & $\begin{array}{r}26(62) \\
18(86) \\
8(33)\end{array}$ & $\begin{array}{r}16(38) \\
3(14) \\
13(67)\end{array}$ & $\begin{array}{l}30(71) \\
20(96) \\
10(47)\end{array}$ & $\begin{array}{r}12(29) \\
1 \quad(4) \\
11(53)\end{array}$ & $\begin{array}{l}35(83) \\
20(96) \\
15(71)\end{array}$ & $\begin{array}{l}7(17) \\
1 \quad(4) \\
6(29)\end{array}$ \\
\hline
\end{tabular}

Percentages are given in parentheses. 
Table 4 Correlation between severity of haemophilia (see Methods), liver function tests, and presence of antibodies to $C M V, E B V$, and $\mathrm{HBs} A g$

\begin{tabular}{|c|c|c|c|c|c|c|}
\hline \multirow[t]{2}{*}{ Disease severity } & \multirow{2}{*}{$\begin{array}{l}\text { Number of } \\
\text { patients }\end{array}$} & \multicolumn{2}{|c|}{ Liver function tests } & \multicolumn{3}{|c|}{ Positive serology } \\
\hline & & Normal & Abnormal & $C M V$ & $E B V$ & $H B s A g$ \\
\hline $\begin{array}{l}\text { Severe } \\
\text { Moderately severe } \\
\text { Mild }\end{array}$ & $\begin{array}{r}30 \\
4 \\
8\end{array}$ & $\begin{array}{rr}12 & (40) \\
1 & (25) \\
8 & (100)\end{array}$ & $\begin{array}{r}18(60) \\
3(75) \\
0(0)\end{array}$ & $\begin{array}{r}21(70) \\
2(50) \\
3(38)\end{array}$ & $\begin{array}{r}23(77) \\
3(75) \\
4(50)\end{array}$ & $\begin{array}{r}27(90) \\
4(100) \\
4 \quad(50)\end{array}$ \\
\hline
\end{tabular}

Percentages are given in parentheses.

borne viruses and therefore may be at greater risk of developing chronic hepatitis. Fifty per cent of our patients had abnormal liver function tests, but without biopsy evidence it is not possible to determine the severity of the underlying pathological process.

With the exception of $\mathrm{HBsAg}$ and probably CMV, this study does not suggest that these patients are at greater risk of exposure to the viruses studied than the general population. The very high incidence of anti-HBs in our population is similar to that found by others (Peterson et al., 1973). However, Burrell et al. (1978) have reported a lower incidence of anti-HBs in their population and showed unequivocal evidence of exposure to $\mathrm{HB}$ virus in only $20 \%$ of patients studied over a five-year period. The incidence of anti-HBs in our study group cannot be explained by the passive transfer of antibody in cryoprecipitate infusions (Cleghorn and Dane, personal communication) and must, therefore, reflect previous exposure to the $\mathrm{HB}$ virus. A recent study of haemophiliacs with abnormal liver function tests and anti-HBs demonstrated HBsAg and hepatitis core antigen in liver biopsy specimens using indirect immunofluorescence techniques (Spero et al., 1978). This suggests that in those patients either virus or viral products were present in the liver and may have been related to the development of chronic progressive liver disease. However, in that series $11 \%$ of patients were persistent carriers of HBsAg. This is a much higher carrier rate when compared to the haemophiliac population in this country.

The overall exposure rate to CMV was higher than normal, and CMV antibody was detected in over $90 \%$ of patients more than 40 years of age. This is particularly high when compared to the normal adult population in this country (Stern, 1972). Most of these patients had received whole blood transfusions in the past and this is the most likely source of infection. It is interesting that patients with no evidence of previous exposure to CMV, EBV, and HBsAg rarely had abnormal liver function. The significance of this finding is at present unknown. The incidence of antibodies detected to hepatitis A was similar to that found in a small number of sera from the general population. However, hepatitis $A$ is probably a very rare cause of post-transfusion hepatitis (Dienstag et al., 1977).

While raised antibody titres to measles and rubella viruses have been reported previously in patients with chronic hepatitis (Triger et al., 1972; Laitinen and Vaheri, 1974), titres were generally low (less than $1: 64$ ) in our patients.

The long-term significance of abnormal liver function tests in these patients is unclear. In those patients with persistently high transaminase levels, a liver biopsy may be indicated in order to obtain a pathological diagnosis. Whether those patients with chronic active hepatitis should be given specific therapy, for example, corticosteroids, will be a matter for consideration. In non-haemophiliacs, persistently abnormal liver function tests have been reported after an episode of non-A, non-B posttransfusion hepatitis, and liver biopsies showed chronic active hepatitis (Knodell et al., 1977). Such viruses have been incriminated as causing acute hepatitis in haemophiliacs after factor VIII replacement therapy (Craske et al., 1978). The relationship of the non-A, non-B hepatitis virus or viruses to chronic asymptomatic liver disease in haemophiliacs is unknown. The recent demonstration of the ability to transfer this agent(s) from human sera to animals (Alter et al., 1978; Tabor et al., 1978), and the development of an immunoassay (Prince, 1978), are promising tools for research into this particular problem.

We are grateful to Dr S. D. Gardner, consultant virologist, Virus Reference Laboratory, for advice and assistance, and to the late Dr Katherine $M$. Dormandy, Director, Haemophilia Centre, Royal Free Hospital, for permission to study her patients.

\section{References}

Aledort, L. M. (1977). The cause of death in haemophiliacs. In Unresolved Therapeutic Problems in Haemophilia, edited by D. L. Arcnson, and J. Fratantoni, (DHEW Publication no. (NIH) 77-1089), 
National Institutes of Health, Bethesda.

Alter, H. J., Purcell, R. H., Holland, P. V., and Popper, H. (1978). Transmissible agent in non-A, non-B hepatitis. Lancet, 1, 459-463.

Biggs, R. (1974). Jaundice and antibodies directed against factors VIII and IX in patients treated for haemophilia or Christmas Disease in the United Kingdom. British Journal of Haematology, 26, 313-329.

Bradstreet, C. M. P. and Taylor, C. E. D. (1962). Technique of complement-fixation test applicable to the diagnosis of virus diseases. Monthly Bulletin of the Ministry of Health and the Public Health Laboratory Service, 21, 96-104.

Burrell, C. J., Black, S. H., and Ramsay, D. M. (1978). Antibody to hepatitis B surface antigen in haemophiliacs on long-term therapy with Scottish factor VIII. Journal of Clinical Pathology, 31, 309-312.

Craske, J., Kirk, P., Cohen, B., and Vandervelde, E. M. (1978). Commercial factor VIII associated hepatitis, 1974-75, in the United Kingdom: a retrospective survey. Journal of Hygiene, 80, 327-336.

Dienstag, J. L., Feinstone, S. M., Purcell, R. H., Wong, D. C., Alter, H. J., and Holland, P. V. (1977). Non-A, non-B post-transfusion hepatitis. Lancet, 1, 560-562.

Hasiba, U. M., Spero, J. A., and Lewis, J. H. (1977). Chronic liver dysfunction in multitransfused hemophiliacs. Transfusion, 17, 490-494.

Hilgartner, M. W. and Giardina, P. (1977). Liver dysfunction in patients with hemophilia, A, B and von Willebrand's disease. Transfusion, 17, 495-499.

Knodell, R. G., Conrad, M. E., and Ishak, K. G. (1977). Development of chronic liver disease after acute non-A, non-B post-transfusion hepatitis. Role of y-globulin prophylaxis in its prevention. Gastroenterology, 72, 902-909.

Laitinen, O. and Vaheri, A. (1974). Very high measles and rubella virus antibody titres associated with hepatitis, systemic lupus erythematosus, and infectious mononucleosis. Lancet, 1, 194-198.

Lesesne, H. R., Morgan, J. E., Blatt, P. M., Webster, W. P., and Roberts, H. R. (1977). Liver biopsy in hemophilia A. Annals of Internal Medicine, 86, 703-707.

Levine, P. H., McVerry, B. A., Attock, B., and Dormandy, K. M. (1977). Health of the intensively treated hemophiliac, with special reference to abnormal liver chemistries and splenomegaly. Blood, 50, 1-9.

Lewis, J. H. (1970). Hemophilia, hepatitis and HAA. Vox Sanguinis, 19, 406-409.

McVerry, B. A., Voke, J., Mohammed, I., Dormandy, K. M., and Holborow, E. J. (1977). Immune complexes and abnormal liver function in haemophilia. Journal of Clinical Pathology, 30, 1142-1146.

Mannucci, P. M., Capitanio, A., Del Ninno, E., Colombo,
M., Pareti, F., and Ruggeri, Z. M. (1975). Asymptomatic liver disease in haemophiliacs. Journal of Clinical Pathology, 28, 620-624.

Peterson, M. R., Barker, L. F., and Schade, D. S. (1973). Detection of antibody to hepatitis-associated antigen in hemophilia patients and in voluntary blood donors. Vox Sanguinis, 24, 66-75.

Prince, A. M. (1978). Proceedings of the Second University of California, San Francisco Symposium on Viral Hepatitis, San Franciso, March 16-19.

Spero, J. A., Lewis, J. H., Van Thiel, D. H., Hasiba, U., and Rabin, B. S. (1978). Asymptomatic structural liver disease in hemophilia. New England Journal of Medicine, 298, 1373-1378.

Stern, H. (1972). Cytomegalovirus and EB virus infections of the liver. British Medical Bulletin, 28, 180-185.

Sultan, Y., Maisonneuve, P., Simeon, J., and Intrator, L. (1977). Modifications of factor VIII related antigen in haemophiliacs with acute hepatitis and sub-clinical liver disease. Scandinavian Journal of Haematology, no. 30, 16-26.

Tabor, E., Gerety, R. J., Drucker, J. A., Seeff, L. B., Hoofnagle, J. H., Jackson, D. R., April, M., Barker, L. F., and Pineda-Tamondong, G. (1978). Transmission of non-A, non-B hepatitis from man to chimpanzee. Lancet, 1, 463-466.

Thornton, A., Tsiquaye, K. N., and Zuckerman, A. J. (1977). Studies on human hepatitis A virus in chimpanzees. British Journal of Experimental Pathology, 58, 352-358.

Triger, D. R., Kurtz, J. B., MacCallum, F. O., and Wright, R. (1972). Raised antibody titres to measles and rubella viruses in chronic active hepatitis. Lancet, 1, 665-667.

Wallace, J. (1976). Blood transfusion and transmissible disease. Clinics in Haematology, 5, 183-200.

Webster, W. P., Blatt, P. M., and Lesesne, H. R. (1977). Liver function tests in haemophiliacs. In Unresolved Therapeutic Problems in Haemophilia, edited by D. L. Aronson and J. Fratantoni, (DHEW Publication no. (NIH) 77-1089), National Institutes of Health, Bethesda.

Yannitsiotis, A., Bossinakou, I., Louizou, C., Panayotopoulou, A., and Mandalaki, T. (1977). Jaundice and hepatitis B surface antigen and antibody in Greek haemophiliacs. Scandinavian Journal of Haematology, Supplement, No. 30, 11-15.

Requests for reprints to: Dr B. A. McVerry, Department of Clinical Haematology, University College Hospital Medical School, 98 Chenies Mews, London WC1E 6HX, UK. 